\title{
Opportunities and Challenges of Universitas Negeri Surabaya in Fulfillment of the Rights of Education for People with Mentally Retardation
}

\author{
Pudji Astuti ${ }^{1, *}$ Anam Miftakhul Huda ${ }^{2}$ Rr Nanik Setyowati ${ }^{3}$ \\ ${ }^{1}$ Law Department, Universitas Negeri Surabaya, Surabaya, Indonesia \\ ${ }^{2}$ Communication Department, Universitas Negeri Surabaya, Surabaya, Indonesia \\ ${ }^{3}$ Department Of Pancasila and Citizenship Education, Universitas Negeri Surabaya, Surabaya, Indonesia \\ *Corresponding author.Email: pudjiastuti@unesa.ac.id
}

\begin{abstract}
The advantages of this study are to identify the problems accomplished by universities in fulfilling the educational rights of people with mental retardation in obtaining services in the teaching and learning process, and describe the efforts to solve the problems experienced by Universitas Negeri Surabaya in implementing the teaching and learning process for people with mental retardation; this research method uses a qualitative approach which results in a descriptive implementation of the learning process for mentally retarded students at Universitas Negeri Surabaya. Data were collected using field observation methods, Focus Group Discussion (FGD), and in-depth interviews. Primary data were obtained through participating observation techniques and in-depth interviews. This research is also strengthened by extracting secondary data. The outcome of this research shows that the fulfillment of the right to intellectually latest education at Universitas Negeri Surabaya has been as maximal as possible but it cannot be balanced with the ability of mentally retarded students, who incidentally have IQs between 50-70. Mentally retarded students find it difficult to accept lecture materials and assign teaching and learning activities. Recommendations in this research, Universitas Negeri Surabaya should be more prepared in the process of accepting mentally retarded students, the learning process and evaluation process for students, and the formation of a special team for handling mental retardation in collaboration with PSLD (Center for Disability Studies and Services).
\end{abstract}

Keywords: University, Right to Education, Mental Retardation, Universitas Negeri Surabaya

\section{INTRODUCTION}

One of the national aims of the Indonesian state as stated in Paragraph IV of the Preamble to the 1945 Constitution of the Republic of Indonesia of the Preamble to the 1945 Constitution of the Republic of Indonesia (UUD NRI 1945) is to educate the nation's life. It means the state is overseeing the intelligence of all its citizens, without exception, including persons who have disabilities.

The law stipulates that persons who have disabilities are entitled to special treatment in obtaining an education. Article $28 \mathrm{H}$ paragraph (2) of the 1945 Constitution of the Republic of Indonesia stipulates that "Every people has the same right to get facilities and special services to obtain the same occasions and advantages to reach equality and justice".
Based on these provisions, Article 5 paragraph (2) of Law Number 20 of 2003 concerning the National Education System (UU Sisdiknas) stipulates that "Citizens who have physical, emotional, mental, intellectual, and/or social disorders are entitled to special education". It means to provide maximum protection for persons with disabilities. including the right to education, the preamble to Law Number 8 of 2016 concerning Persons with Disabilities which revokes Law no. 4 of 1997 concerning Persons with Disabilities (Law on Disabilities) letter c stipulates that: "to realize equal rights and opportunities for persons with disabilities to live a prosperous, independent, and non-discriminatory life, laws, and regulations are needed that can guarantee their implementation" Article 5 paragraph (1) The Disability Law stipulates that "the government and local governments area are obliged to realize the rights persons 
who have disabilities to education". In accordance with article 40 paragraph (1) of the Law on Disabilities, stated that "The government and local governments are indebted to regulate and/or facilitate education for persons who have disabilities in every path, type, and level of education in accordance with their authority". Efforts to improve social welfare for Persons with Intellectual Disabilities or mentally retarded are an integral part of National Development [1]

The Constitution of the Minister of Education and Culture Number 46 of 2014 related to Special Education in Higher Education does not further regulate the learning process for people with intellectual disabilities that require special treatment. It is very important to regulate considering that evidence from the Ministry of Education and Culture illustrates the fact that in October 2019 in Indonesia there were 3240 vocational and high school students while the total number of people with disabilities was 91 thousand people with disabilities who should have been registered in vocational or high school. Of the 3240 students enrolled in SMK and SMU, some of them are prospective students in various universities. The results of the Research on Identifying the Needs of Students with Disabilities after High School" show that they need job vacancies and opportunities to continue their education [2].

Mental retardation is a child who has intellectual limitations. They have slower adjustment abilities than other children of their age [3]

Based on Law Number 8 of 2016 related to Persons who have Disabilities, however, the rights of children with disabilities have not been optimally fulfilled. It can be proven by: 1) it still many children who have disabilities who experience stigma, discrimination, violence, labeling, and exploitation; 2) there are still many children with disabilities who have not received services in the fields of health, education, religion, social welfare, services in disaster areas, and rehabilitation, child identity, training and mentoring; 3) not much accessibility has been given to children with disabilities; 4) there are still many children with disabilities who have not had the opportunity to express their opinions and obtain the required information [4].

Universitas Negeri Surabaya is one of the public universities that cares and is friendly to people with disabilities, it is proven that there has been acceptance of students with disabilities starting in 2018 at Universitas Negeri Surabaya, but problems and problems cannot be avoided. This study focuses on the challenges and opportunities of Universitas Negeri Surabaya in fulfilling the rights of mentally retarded students. So that in the future this research is a form of policy contribution in the implementation of disability-friendly tertiary education.

\section{RESEARCH METHOD}

This study uses the qualitative method. This research is descriptive which aims to photograph various phenomena that arise, which are the object of research, then draw to the surface as a feature or description of certain conditions, situations, or phenomena [5]. Data collection is carried out in two ways, namely extracting primary data and secondary data. Primary data is done in three ways. First, observation is done by observing the learning process and evaluating students with mental retardation. Second, in-depth interviews. In-depth interviews were conducted on the admissions committee for new students with mental retardation, lecturers related to mentally retarded students, and students with /.intellectual disabilities at Universitas Negeri Surabaya.

The in-depth interviews aimed to dig up data about the admissions process, the implementation of the Teaching and Learning Proses (PBM), and its evaluation. All information obtained in the field, through the process of observation and in-depth interviews, is recorded in a field note on the same day as the interview to avoid the possibility of forgetting or overlapping information between one informant and another. The interview in this study was conducted with Mr. Dadang, a lecturer in Indonesian, who teaches in the Class of 2019. The Head of the Centre for the Study of Disability Services (PSLD) Unesa Prof. Dr. Budiyanto, Mrs. Ima as the secretary of PSLD, Satiningsih, M.PSi, a lecturer in Psychology at Unesa, Dr. Sukarmin, M.Pd, as Unesa's new student admissions committee, Mr. Jono from BAAK/PSI, Mr. Samuel as the family of UNESA mentally retarded students.

Triangulation is a kind of technique to check the validity of data that utilizes something else, the result of the data to check purposes or as a comparison against data. In qualitative research, the triangulation technique is used to check the validity of the data from the interview done by the researcher, then the researcher looks at the documentation related to the research and supports the research as well as the results in the field so that the purity and validity of the data are guaranteed.

\section{RESULT AND DISCUSSION}

\subsection{The Opportunity of Universitas Negeri Surabaya in Fulfilling the Rights of Students with Mentally Retardation}

The right to support higher education must be felt by all people, including Citizens with Special Needs (WNBK) or with disabilities. Unfortunately, education for WNBK is generally still limited to the high school level. It is because Universitas Negeri Surabaya provides an opportunity for WNBK to study in higher education. 
Concerning the provision of the law, it is clear that children with disabilities need to have the same occasions as those given to the other normal children as usual in terms of education and teaching [6].

Opportunities to continue their education to college for them are quite large. If you have relatives, friends, or parents who have children with Special Needs (ABK), you can recommend and encourage them to be able to continue their education to a higher level. This educational equality has inspired several campuses in Indonesia to open special pathways for people with disabilities.

In 2018 Unesa accepted 14 new students from the disability community consisting of people with visual impairments, physical disabilities, and mental retardation spread across all faculties and departments. Not only providing special pathways for disability, but UNESA WNBK students can also follow the SBMPTN and UTBK pathways. There are also special scholarships for students with disabilities. Prospective students who are taking the test will receive two assistances. The first is a personal assistant and companion provided by the campus. This assistant aims to help with all the needs of the activities of prospective Unesa WNBK students during the exam. The LTMPT (University Entrance Test Institute) has also developed a screen reader method to provide accessibility for participants with visual impairments so that they can read text on a computer screen that can be used by prospective WNBK students at UNESA.

The right to education can be interpreted as the development of the potential possessed by a person in order to have religious-spiritual strength, identity, knowledgeable, noble character, and the skills needed for himself and society that he accepted. Because selfdevelopment is a human right in the economic field as well as in the socio-cultural field, this right to education has been regulated in Article 31 paragraph (1) of the 1945 Constitution of the Republic of Indonesia states "Every people has the same right of education". Thus people with mental retardation are also entitled to a proper education.

Based on Article 31 (1) of the 1945 Constitution of the Republic of Indonesia, Law no. 39 of 1999 concerning Human Rights, in which Article 54 stipulates that "Every child who is physically or mentally disabled, they have the same right to receive special care, education, training, and assistance at the expense of the state, to ensure his life in accordance with human dignity, to improve himself and his abilities, participate in the life of society and the state"

With special approaches and strategies in educating children who have disabilities, it is hoped that children with disabilities: (1) they can accept their own condition, (2) they can socialize well, (3) they can fight according to their abilities, (4) they have skills that are needed, and (5) they realized as citizens and members of society [7].

\subsection{The Challenges of Universitas Negeri Surabaya in Fulfilling the Rights of Students with Mentally Retardation}

There is an increase in special tests for mentally retarded to choose majors that are following the abilities of students. Children who have special needs are children who are born with special needs that are different with humans as usual in general so they require special services [8].

It is because UNESA already has administrative procedures for admitting new students with disabilities, which was carried out in 2018 and is still the same as normal students, but in 2019 and 2020, it has had its component, namely $40 \%$ of the administration including high school diplomas, justification tests from doctors, tests psychologist to determine the level of intelligence, school accreditation, competition certificate if any.

Assessment Weight $40 \%$ of the evaluation desk passes, then prospective students will be interviewed by the PLSD TEAM which includes psychologists, doctors, and Arthopedagogics who have a weight value of $60 \%$.

The learning process is still the same as for normal students, so that since 2019 volunteer assistants have been provided based on the request of active students to help mentally retarded students in carrying out teaching and learning activities. Lecture materials are the same as students in general and assessments are also the same as students in general. It actually cannot be equated with normal students so that those who feel disadvantaged are of course very detrimental to them, considering their limitations.

It is conveyed by the lecturer that the opinion of the ability to digest mentally retarded students is very less even if it is only equivalent to elementary school.

"Indeed, his cognitive ability is only equivalent to a low-grade elementary school, it is difficult to digest lecture material" Dadang

It was also conveyed by Ima, the Secretary of the Center for Disability Study Services. Most of the lecturers objected and thought that mentally retarded students hindered learning, so it was necessary to hold special classes so it was not disrupting schooling enterprise. It is essential to improve communication between lecturers and students with mental retardation that is more intensive because many students complain and are burdened if there are students with mental retardation in one assignment group because the ability to master the material for mentally retarded students is below $50 \%$. They have an IQ ranging from 4O-54. In general, they can barely learn academic materials (reading, writing, and arithmetic) [9]. 


\section{CONCLUSION}

The 0pportunities of Universitas Negeri Surabaya provide learning opportunities for mentally retarded students in higher education. Based on the provisions of this law, it is clear that children with disabilities need to have the same occasion as those given to other normal children in terms of education and teaching. The challenge is Universitas Negeri Surabaya must prepare facilities and human resources or lecturers who can communicate with mentally retarded students well so learning can be effective and efficient.

\section{SUGGESTION}

Based on the discussion above, this study concludes as follows, for the sustainability of mentally retardedfriendly universities in the future.

1. The recruitment process for students is more thorough, for example, there is an IQ test if it is between 50-70 that they should not be accepted because their ability to go to college cannot be achieved in the learning process.

2. If it is forced to be accepted then in some Vocational Study Programs which are more skilled, such as catering, make-up or fashion. It is necessary to prepare a special program that teaches skills so that they are experts in one field with evidence of a certificate of special expertise.

3. During learning, it is necessary to prepare lecturers who receive special training in handling mentally retarded students as well as the existence of volunteer student assistants to facilitate the teaching and learning process.

4. Increasing collaboration with various study programs related to the needs of mentally retarded students, especially with PSLD UNESA which is responsible for managing students with disabilities in Unesa.

5. It needs a written rule regarding the accomplishmentt of the Educational Rights of Persons with Disabilities that can be used as guidelines for the implementation of their rights at UNESA.

\section{ACKNOWLEDGMENTS}

We would like to express our gratitude to Universitas Negeri Surabaya, a place the researchers serve, and all those who helped carry out this research. Thank you, Faculty of Social and Law, State University of Surabaya for facilitating the 2021 PNBP funding so this research runs well.

\section{REFERENCES}

[1] H. Hanafi, "Implementasi Kebijakan Rehabilitasi Sosial Penyandang Tuna Grahita Di Panti Sosial Bina Grahita Nipotowe Palu," Katalogis, vol. 3, no. 11 .

[2] U. F. Rizky, "Identifikasi kebutuhan siswa penyandang disabilitas pasca sekolah menengah atas," IJDS Indones. J. Disabil. Stud., vol. 1, no. $1,2014$.

[3] A. A. ZF, A. Bakar, and F. Fajriani, "Persepsi orang tua serta dukungan pendidikan terhadap anak tuna grahita di Kecamatan Meureudu dan Meurah Dua Pidie Jaya," JIMBK J. Ilm. Mhs. Bimbing. Konseling, vol. 4, no. 1, 2019.

[4] F. Husna, N. R. Yunus, and A. Gunawan, "Hak Mendapatkan Pendidikan Bagi Anak Berkebutuhan Khusus Dalam Dimensi Politik Hukum Pendidikan," SALAM J. Sos. dan Budaya Syar-i, vol. 6, no. 2, pp. 207-222, 2019.

[5] D. Lum'ah, M. Efendi, and D. A. Dewantara, "The Effectiveness of the Picture and Picture Learning Model to Improve the Teeth Brushing Ability of Intellectual Disability," $J$. ORTOPEDAGOGIA, vol. 6, no. 2, pp. 83-87, 2020.

[6] M. Neli, J. Indrawadi, and I. Isnarmi, "Penguatan Pendidikan Karakter Mandiri Anak Berkebutuhan Khusus Tunagrahita di Panti Sosial Bina Grahita 'Harapan Ibu' Padang," J. Civ. Educ., vol. 3, no. 2, pp. 172-177, 2020.

[7] M. Efendi, "Pengantar psikopedagogik anak berkelainan," 2006.

[8] S. F. M. Sari, B. BINAHAYATI, and B. M. TAFTAZANI, "Pendidikan bagi anak tuna grahita (Studi kasus tunagrahita sedang di SLB N Purwakarta)," Pros. Penelit. Dan Pengabdi. Kpd. Masy., vol. 4, no. 2, 2017.

[9] A. Supena, "Model Pendidikan Inklusif Untuk Siswa Tunagrahita Di Sekolah Dasar," Param. J. Pendidik. Univ. Negeri Jakarta, vol. 29, no. 2, pp. 145-155, 2017. 